\title{
Nutrient Index of Available $S$ in Soils of Howrah and South Dinajpur Districts of West Bengal, India
}

\author{
Rahul Kumar $^{1 *}$, Gora Chand Hazra ${ }^{1}$, Ruma Das ${ }^{2}$, \\ Shyam Prasad Majumder ${ }^{1}$ and Amal Chandra Das ${ }^{1}$ \\ ${ }^{1}$ Division of Agricultural Chemistry and Soil Science, Bidhan Chandra Krishi \\ Viswavidyalaya, Mohanpur, Nadia, West Bengal, India \\ ${ }^{2}$ Division of Soil Science and Agricultural Chemistry, ICAR-IARI Pusa Campus, \\ New Delhi, India \\ *Corresponding author
}

\section{A B S T R A C T}

\begin{tabular}{|l|}
\hline Ke y w o r d s \\
Nutrient Index, \\
Howrah, South \\
Dinajpur, Fertility \\
Status, Soil \\
properties, \\
Inceptisols \\
\hline Article Info \\
\hline Accepted: \\
10 March 2019 \\
Available Online: \\
10 April 2019 \\
\hline \hline
\end{tabular}

Nutrient index of available $S$ in soils of two districts, namely, Howrah and South Dinajpur of West Bengal falling in the soil order Inceptisols collecting 237 soil samples from Howrah and 256 soil samples from South Dinajpur district. Soil samples were collected according to grid sampling pattern maintaining approximately $4.0 \mathrm{~km}$ grid for Howrah and $3.7 \mathrm{~km}$ grid for South Dinajpur district using global positioning system (GARMIN GPS Version etrex) covering 13 blocks of Howrah and 8 blocks of South Dinajpur district. Soil $\mathrm{pH}$ of the Howrah and South Dinajpur district ranged from 3.0to 8.30 with a mean value of 5.75 and 3.7 to 7.0 with a mean value of 5.21.The organic carbon content in soils of Howrah and South Dinajpur district ranged from 0.18 to $1.21 \%$ with a mean value of $0.55 \%$ and 0.37 to $1.32 \%$ with a mean value of $0.84 \%$. Available $\mathrm{S}$ content in soils of Howrah and South Dinajpur district ranged from 1.09 to $78.70 \mathrm{mg} \mathrm{kg}^{-1}$ with a mean value of $18.12 \mathrm{mg} \mathrm{kg}^{-1}$ and2.03 to $43.39 \mathrm{mg} \mathrm{kg}^{-1}$ with a mean value of $10.52 \mathrm{mg} \mathrm{kg}^{-1}$. Nutrient index value (NIV) of available soil $\mathrm{S}$ of these two districts was 1.38 and 1.10. Results revealed that available soil S status of Howrah and South Dinajpur is medium and low.

\section{Introduction}

Intensive cropping system with high yielding varieties for boosting food production caused marked depletion of inherent nutrient reserves in soil. Consequently along with deficiency of $\mathrm{N}, \mathrm{P}$ and $\mathrm{K}$, the deficiency of secondary and micronutrients are frequently reported. Among the secondary nutrients a good response to sulphur fertilizers has been reported by many authors (Narendranath,
2005; Jena et al., 2006). Total sulphur content of Indian soils was between 19 and $3836 \mathrm{mg}$ $\mathrm{kg}^{-1}$ and it varies in amounts depending upon its content in the primary minerals, organic compounds and in the soil solution (Renuka devi et al., 2002). In India, the some scientists have been reported that about $40 \%$ soils were low, $35 \%$ in medium and $25 \%$ in high category in sulphur (Motsara, 2002). Mukhopadhyay and Mukhopadhyay (1980) studied twelve selected soil series or five 
major soil zones of West Bengal and showed that $\mathrm{CaCl}_{2}$ extractable $\mathrm{S}$ varied between 0.6 $\mathrm{mg} \mathrm{kg}$ (1.2 kg S ha $\left.{ }^{-1}\right)$ to $217.2 \mathrm{mg} \mathrm{kg}^{-1}$ (434.4 kg S ha ${ }^{-1}$ ). Dolui and Pramanik (2001) studied the vertical distribution of sulphur in the three profiles of Alfisols of West Bengal and showed that $\mathrm{CaCl}_{2}$ extractable sulphur decreased with the increasing depth. Sarkar (1996) studied the vertical distribution of different forms of sulphur in ten established soil series of West Bengal belong to the Inceptisols order and reported that different form of sulphur including $\mathrm{CaCl}_{2}$ extractable sulphur. They showed a decreasing trend of available $\mathrm{S}$ with increasing the depth of the profile. About $70 \%$ soils were found to be sulphur deficient in the investigated series. Three soil series which were non deficient in sulphur were located in rainfed, coastal saline zone. Basak et al., (2002) determine the nutrient index for sulphur of individual mouzas of Amedanga block; they reported that the sulphur status of the block was low. Sulphur deficient areas in block widespread. In Tamil Nadu sulphur deficiency between 7 40 per cent has been reported and mostly red soils coming under Alfisols, low level laterite soils and alluvial soils with low organic status are found to have more sulphur deficiency than any other soils (Sankaran, 1989).

A preliminary investigation carried out in Tamil Nadu has shown that the occurrence of sulphur deficiency was more than 40 per cent in Madurai, Villupuram, Thiruvannamalai and Thiruvallur districts, between $20-40$ per cent in Coimbatore, Erode, Trichy and Dindugal districts, less than 20 per cent in Thanjavur, Tuticorin, Kanyakumari, Ramnad and Nilgris (Arunageetha, 2001; Maragatham, 2001). Sahrawat et al., (2007) studied on widespread deficiencies of sulphur, boron and zinc in dryland soils of the Indian semi-arid tropics. They reported that out of 1926 field samples soil sulphur status ranged from 0.23 to 98.0 $\mathrm{mg} \mathrm{kg}{ }^{-1}$ with a mean value of $5.6 \mathrm{mg} \mathrm{kg}^{-1}$.
Singh et al., (2012) reported that the available sulphur status of chiraigaon block of Varanasi district (U.P.) ranges from $6.0-16.6 \mathrm{mg} \mathrm{kg}^{-1}$ with a mean value $9.5 \mathrm{mg} \mathrm{kg}^{-1}$ i.e. low. Therefore, imperative to identify the areas with respect to the sufficiency or deficiency of this element under different situations in relation to soils, climate, crop species and cropping systems. Information on the $S$ status of alluvial soils under rice-rice cropping system was lacking. With this background the present study was undertaken to delineate sulphur deficient areas in Howrah and South Dinajpur district of West Bengal.

\section{Materials and Methods}

In order to delineate $S$ in soils of Howrah and South Dinajpur districts of West Bengal falling in the soil order Inceptisols collecting 237 soil samples from Howrah and 256 soil samples from South Dinajpur district was calculated and presented in this section. Soil samples were collected according to grid sampling pattern maintaining approximately $4.0 \mathrm{~km}$ grid for Howrah and $3.7 \mathrm{~km}$ grid for South Dinajpur district using global positioning system (GARMIN GPS Version etrex) covering 13 blocks of Howrah and 8 blocks of South Dinajpur district (Fig. $1 \& 2$ ).

Immediately after collection soil samples were dried, grounded, screened through $2 \mathrm{~mm}$ nylon sieve and stored in plastic container. Then soil samples were analyzed for basic chemical properties viz. soil $\mathrm{pH}$ and organic carbon as well as $0.15 \% \mathrm{CaCl}_{2}$ extractable $\mathrm{S}$ by turbidimetric method (Williams and Steinberg, 1959) for inter-relationship study. Soil samples were categorized as deficient, low, medium and high on the basis of their availability in soils (Singh, 2009). Nutrient index value (Ramamurthy and Bajaj 1969) for soil samples of each district was calculated from the proportion of soils under low (deficient plus low), medium and high 
available nutrient categories and is represented below:

\begin{tabular}{|l|l|l|l|}
\hline \multicolumn{4}{|l|}{ Nutrient Index } \\
\hline $\begin{array}{l}\text { Ramamoorthy and } \\
\text { Bajaj (1969) }\end{array}$ & $<1.7$ & 1.71 to2.33 & $>2.33$ \\
\hline
\end{tabular}

Formula how to calculate Nutrient index value

Nutrient index value $=\frac{N l * 1+N m * 2+N h * 3}{N l+N m+N h}$

Where,

$\mathrm{N}_{1}=$ Nutrient low in category

$\mathrm{N}_{\mathrm{m}}=$ Nutrient medium in category

$\mathrm{N}_{\mathrm{h}}=$ Nutrient high in category

\section{Results and Discussion}

\section{Soil chemical properties}

\section{Soil pH}

The prominent soil in the Howrah district falls under the new alluvial and old alluvial agroclimatic zone of West Bengal. Results showed that soil $\mathrm{pH}$ ranged from 3.0to 8.30 with a mean value of 5.75. From 237 soil samples nearly $42.6 \%$ of soil samples were in the $\mathrm{pH}$ range of below 5.5 (acidic), $42.6 \%$ recorded a $\mathrm{pH}$ range of 5.5-6.5 (slightly acidic), $13.5 \%$ recorded a $\mathrm{pH}$ range of 6.5-7.5 (Neutral) and $1.2 \%$ was in the range of 7.5-8.5 (slightly alkaline). Results also showed that the highest soil $\mathrm{pH}$ was found in Domjur block and the lowest in Amta1 block. The data indicate that the soil $\mathrm{pH}$ is acidic to slightly acidic in reaction, but soils in the South Dinajpur district falls under the old alluvium and lateritic agro-climatic zone. Soil $\mathrm{pH}$ of South Dinajpur ranged from 3.7 to 7.0 with a mean value of 5.21 . Nearly $81.6 \%$ of soil samples were in the $\mathrm{pH}$ range of below 5.5 (acidic), $16.58 \%$ recorded a $\mathrm{pH}$ range of 5.5-6.5 (slightly acidic) and a little number of samples (about 1.5\%) in the $\mathrm{pH}$ range 6.5-7.5 (Neutral) from 256 soil samples. Therefore, results revealed that almost soil samples were acidic in reaction which might be related to the loss of basic cation from soils owing to heavy precipitation. Similarly, Mandal et al., 1979 reported that in West Bengal out of total net cropped area of about 7.5 million hectares, there are about 2.0 million hectares having soils of $\mathrm{pH}$ less than 6.0 (Table 1 and 2).

\section{Soil organic carbon}

Organic carbon content in soils of Howrah district ranged from 0.18 to $1.21 \%$ with a mean value of $0.55 \%$. Results revealed that $41.7 \%$ soil samples were in low category $(<0.75 \%), 47.2 \%$ soil samples were in medium category $(0.75-1.50 \%)$ and $10.9 \%$ was categorized as high $(>1.50 \%)$. On an average, organic carbon content showed mostly a range of low to medium which might be due to follow of intensive cultivation in this district year after year. Organic carbon content in soils of South Dinajpur district ranged from 0.37 to $1.32 \%$ with a mean value of $0.84 \%$. Results also revealed that $3.9 \%$ soil samples were in low category $(<0.75 \%)$, $36.3 \%$ soil samples were in medium category $(0.75-1.50 \%)$ and $59.7 \%$ was categorized as high $(>1.50 \%)$. The data indicate that the soil organic carbon content is medium to high in reaction. Similarly, Singh and Sanyal (2001) reported that the organic carbon content in Kalimpong soil and Matimahal soil of West Bengal was $18.9 \mathrm{~g} \mathrm{~kg}^{-1}$ and $2.3 \mathrm{gkg}^{-1}$, respectively

\section{Available $S$ status and Nutrient Index Value of soil}

Results of available $\mathrm{S}$ content in soils of Howrah showed that it ranged from 1.09 to $78.70 \mathrm{mg} \mathrm{kg}^{-1}$ with a mean value of $18.12 \mathrm{mg}$ $\mathrm{kg}^{-1}$ (Table 3). Results showed that the 
$(33.7 \%)$ soil samples were in deficient category $\left(<10 \mathrm{mg} \mathrm{kg}^{-1}\right), 35.02 \%$ soil samples were in low category $\left(10.0-20.0 \mathrm{mg} \mathrm{kg}^{-1}\right)$ and $24.05 \%$ soil samples were in medium category (20.0-40.0 $\left.\mathrm{mg} \mathrm{kg}^{-1}\right)$, only a very few samples $7.1 \%$ were in the category of high $\left(>40.0 \mathrm{mg} \mathrm{kg}^{-1}\right)$. Nutrient index value (NIV) of available soil $\mathrm{S}$ of this district was also calculated $(\mathrm{NIV}=1.38)$ which further revealed that available soil $\mathrm{S}$ status of Howrah is medium (Table 3 and Fig. 3). The medium $S$ status of Howrah might be related to the intensive cultivation.

Table.1 Block wise $\mathrm{pH}$ and organic carbon content (\%) in soil samples of Howrah district of West Bengal

\begin{tabular}{|l|c|c|c|c|c|c|}
\hline \multirow{2}{*}{ Name of the block } & \multicolumn{3}{|c|}{ pH } & \multicolumn{3}{c|}{ OC (\%) } \\
\cline { 2 - 7 } & Range & Mean & SD $( \pm)$ & Range & Mean & SD $( \pm)$ \\
\hline Shyampur 1 & $4.2-7.7$ & 5.76 & 1.11 & $0.31-0.73$ & 0.54 & 0.15 \\
\hline Shyampur 2 & $5.1-7.4$ & 5.95 & 0.63 & $0.38-0.83$ & 0.59 & 0.13 \\
\hline Sankrail & $5.1-8.3$ & 6.15 & 0.83 & $0.24-0.77$ & 0.47 & 0.17 \\
\hline Domjur & $6.0-7.4$ & 6.55 & 0.44 & $0.34-0.77$ & 0.54 & 0.14 \\
\hline Jagatballavpur & $4.2-6.8$ & 5.75 & 0.64 & $0.31-0.69$ & 0.52 & 0.09 \\
\hline Panchla & $4.3-7.4$ & 5.18 & 0.75 & $0.31-0.78$ & 0.50 & 0.16 \\
\hline Uluberia I & $4.4-7.8$ & 6.07 & 0.73 & $0.27-0.92$ & 0.60 & 0.18 \\
\hline Uluberia 2 & $5.1-7.0$ & 5.92 & 0.54 & $0.23-0.81$ & 0.48 & 0.17 \\
\hline Bagnan 1 & $5.0-7.4$ & 5.90 & 0.77 & $0.39-0.86$ & 0.62 & 0.17 \\
\hline Bagnan 2 & $4.1-7.2$ & 5.77 & 0.89 & $0.30-0.88$ & 0.57 & 0.15 \\
\hline Amta 1 & $4.3-6.4$ & 5.06 & 0.55 & $0.33-1.21$ & 0.76 & 0.25 \\
\hline Amta 2 & $3.0-7.0$ & 5.29 & 0.93 & $0.21-1.02$ & 0.53 & 0.18 \\
\hline Udaynaranpur & $3.4-6.5$ & 5.44 & 0.98 & $0.18-1.21$ & 0.47 & 0.25 \\
\hline
\end{tabular}

Table.2 Block wise $\mathrm{pH}$ and organic carbon content (\%) in soil samples of South Dinajpur district of West Bengal

\begin{tabular}{|l|c|c|c|c|c|c|}
\hline \multirow{2}{*}{ Name of the block } & \multicolumn{3}{|c|}{ pH } & \multicolumn{3}{c|}{ OC (\%) } \\
\cline { 2 - 7 } & Range & Mean & SD $( \pm)$ & Range & Mean & SD( \pm$)$ \\
\hline Tapan & $3.7-6.2$ & 5.23 & 0.42 & $0.39-1.05$ & 0.87 & 0.14 \\
\hline Balurghat & $4.0-6.0$ & 5.14 & 0.47 & $0.48-0.99$ & 0.87 & 0.13 \\
\hline Gangarampur & $4.2-6.5$ & 5.28 & 0.53 & $0.51-1.50$ & 0.9 & 0.23 \\
\hline Kushmandi & $4.5-6.3$ & 5.24 & 0.35 & $0.45-1.08$ & 0.80 & 0.14 \\
\hline Hili & $4.3-5.9$ & 5.08 & 0.36 & $0.51-1.35$ & 0.90 & 0.19 \\
\hline Kumarganj & $4.1-6.3$ & 4.98 & 0.44 & $0.37-1.32$ & 0.83 & 0.23 \\
\hline Harirampur & $4.4-7.0$ & 5.56 & 0.66 & $0.45-1.17$ & 0.80 & 0.17 \\
\hline Banshihari & $4.2-6.1$ & 5.17 & 0.40 & $0.39-1.14$ & 0.80 & 0.16 \\
\hline
\end{tabular}


Table.3 Block wise available $\mathrm{S}$ content $\left(\mathrm{mg} \mathrm{kg}^{-1}\right)$ of soil samples as well as NIV of S in Howrah district of West Bengal

\begin{tabular}{|c|c|c|c|c|c|c|c|c|c|}
\hline \multirow{2}{*}{$\begin{array}{l}\text { Name of the } \\
\text { block }\end{array}$} & \multirow{2}{*}{$\begin{array}{c}\text { No. of } \\
\text { samples } \\
\text { analyzed }\end{array}$} & \multirow{2}{*}{$\begin{array}{c}\text { Range } \\
\left(\mathrm{mg} \mathrm{kg}^{-1}\right)\end{array}$} & \multirow{2}{*}{$\begin{array}{c}\text { Mean } \\
(\mathrm{mg} \\
\left.\mathrm{kg}^{-1}\right)\end{array}$} & \multirow[t]{2}{*}{ SD $( \pm)$} & \multirow{2}{*}{$\begin{array}{l}\text { Per cent } \\
\text { samples } \\
\text { deficient }\end{array}$} & \multicolumn{3}{|c|}{ No. of samples falling in the } & \multirow[t]{2}{*}{ NIV } \\
\hline & & & & & & $\begin{array}{l}\text { Low }+ \\
\text { Deficient }\end{array}$ & Medium & High & \\
\hline Shyampur 1 & 17 & $5.39-78.62$ & 26.8 & 20.06 & 23.52 & 8 & 5 & 4 & 1.76 \\
\hline Shyampur 2 & 17 & $5.34-72.53$ & 27.91 & 18.96 & 11.76 & 8 & 5 & 4 & 1.76 \\
\hline Sankrail & 14 & $11.88-52.88$ & 23.13 & 12.40 & 0 & 6 & 6 & 2 & 1.71 \\
\hline Domjur & 18 & $3.21-48.83$ & 17.03 & 13.48 & 44.44 & 11 & 6 & 1 & 1.44 \\
\hline Jagatballavpur & 17 & $2.84-43.65$ & 18.26 & 13.80 & 41.18 & 11 & 4 & 2 & 1.47 \\
\hline Panchla & 15 & $1.09-20.97$ & 11.22 & 5.66 & 40 & 14 & 1 & 0 & 1.07 \\
\hline Uluberia I & 28 & $3.58-63.38$ & 20.62 & 13.65 & 28.57 & 18 & 9 & 1 & 1.39 \\
\hline Uluberia 2 & 17 & $5.12-38.61$ & 18.16 & 9.67 & 23.53 & 9 & 8 & 0 & 1.47 \\
\hline Bagnan 1 & 8 & $3.02-42.21$ & 21.57 & 13.08 & 12.5 & 4 & 3 & 1 & 1.63 \\
\hline Bagnan 2 & 16 & $5.12-23.29$ & 15.16 & 5.16 & 12.5 & 13 & 3 & 0 & 1.19 \\
\hline Amta 1 & 12 & $1.72-21.07$ & 10.18 & 7.26 & 58.33 & 10 & 2 & 0 & 1.17 \\
\hline Amta 2 & 35 & $1.81-27.74$ & 10.61 & 6.76 & 54.29 & 32 & 3 & 0 & 1.09 \\
\hline Udaynaranpur & 23 & $2.27-78.70$ & 14.87 & 17.69 & 52.17 & 19 & 2 & 2 & 1.26 \\
\hline
\end{tabular}

Nutrient Index Value: Low <1.34, Medium 1.34-2.33, High >2.33, SD: Standard Deviation

Table.4 Block wise available $\mathrm{S}$ content $\left(\mathrm{mg} \mathrm{kg}^{-1}\right)$ of soil samples as well as NIV of S in South Dinajpur district of West Bengal

\begin{tabular}{|c|c|c|c|c|c|c|c|c|c|}
\hline \multirow{2}{*}{$\begin{array}{c}\text { Name of the } \\
\text { block }\end{array}$} & \multirow{2}{*}{$\begin{array}{c}\text { No. of } \\
\text { samples } \\
\text { analyzed }\end{array}$} & \multirow{2}{*}{$\begin{array}{c}\text { Range } \\
\left(\mathrm{mg} \mathrm{kg}^{-1)}\right.\end{array}$} & \multirow{2}{*}{$\begin{array}{c}\text { Mean } \\
(\mathrm{mg} \\
\left.\mathrm{kg}^{-1}\right)\end{array}$} & \multirow{2}{*}{$\begin{array}{l}\text { SD } \\
( \pm)\end{array}$} & \multirow{2}{*}{$\begin{array}{l}\text { Per cent } \\
\text { samples } \\
\text { deficient }\end{array}$} & \multicolumn{3}{|c|}{ No. of samples falling in the } & \multirow[t]{2}{*}{ NIV } \\
\hline & & & & & & $\begin{array}{l}\text { Low+ } \\
\text { Deficient }\end{array}$ & Medium & High & \\
\hline Tapan & 39 & $2.70-26.00$ & 9.15 & 5.32 & 64.10 & 38 & 1 & 0 & 1.03 \\
\hline Balurghat & 30 & $4.05-26.68$ & 12.27 & 5.74 & 33.33 & 25 & 5 & 0 & 1.17 \\
\hline Gangarampur & 29 & $2.53-43.39$ & 16.01 & 10.05 & 27.59 & 21 & 7 & 1 & 1.31 \\
\hline Kushmandi & 26 & $2.70-40.01$ & 9.74 & 8.21 & 65.38 & 24 & 1 & 1 & 1.12 \\
\hline Hili & 32 & $3.38-41.70$ & 11.42 & 7.41 & 46.88 & 29 & 2 & 1 & 1.13 \\
\hline Kumarganj & 32 & $3.38-22.79$ & 8.50 & 5.21 & 65.63 & 31 & 1 & 0 & 1.03 \\
\hline Harirampur & 34 & $2.19-23.64$ & 9.78 & 5.44 & 52.94 & 32 & 2 & 0 & 1.06 \\
\hline Banshihari & 34 & $2.03-19.08$ & 7.30 & 3.76 & 79.41 & 34 & 0 & 0 & 1.00 \\
\hline
\end{tabular}

Nutrient Index Value: Low <1.34, Medium 1.34-2.33, High >2.33, SD: Standard Deviation 
Fig.1 Location map of study area

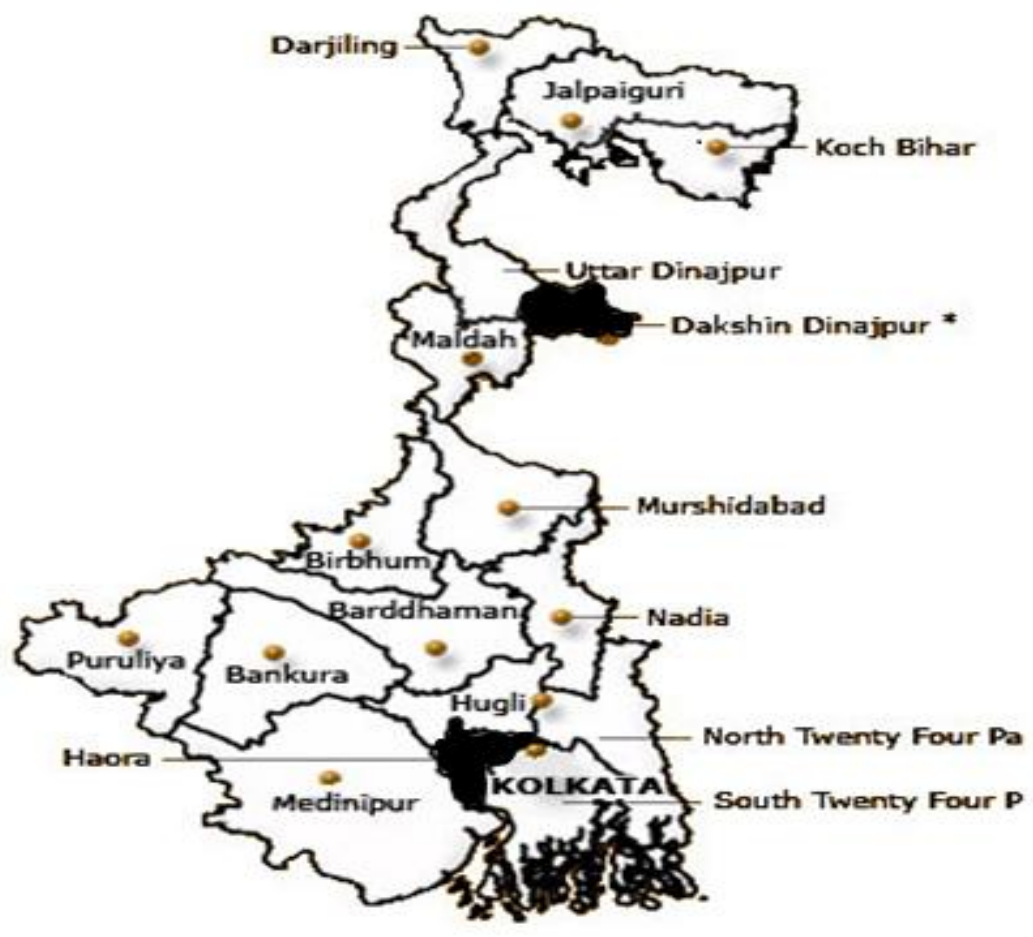

Fig.2 Block wise map location of collected soil samples from Howrah and South Dinajpur district of West Bengal
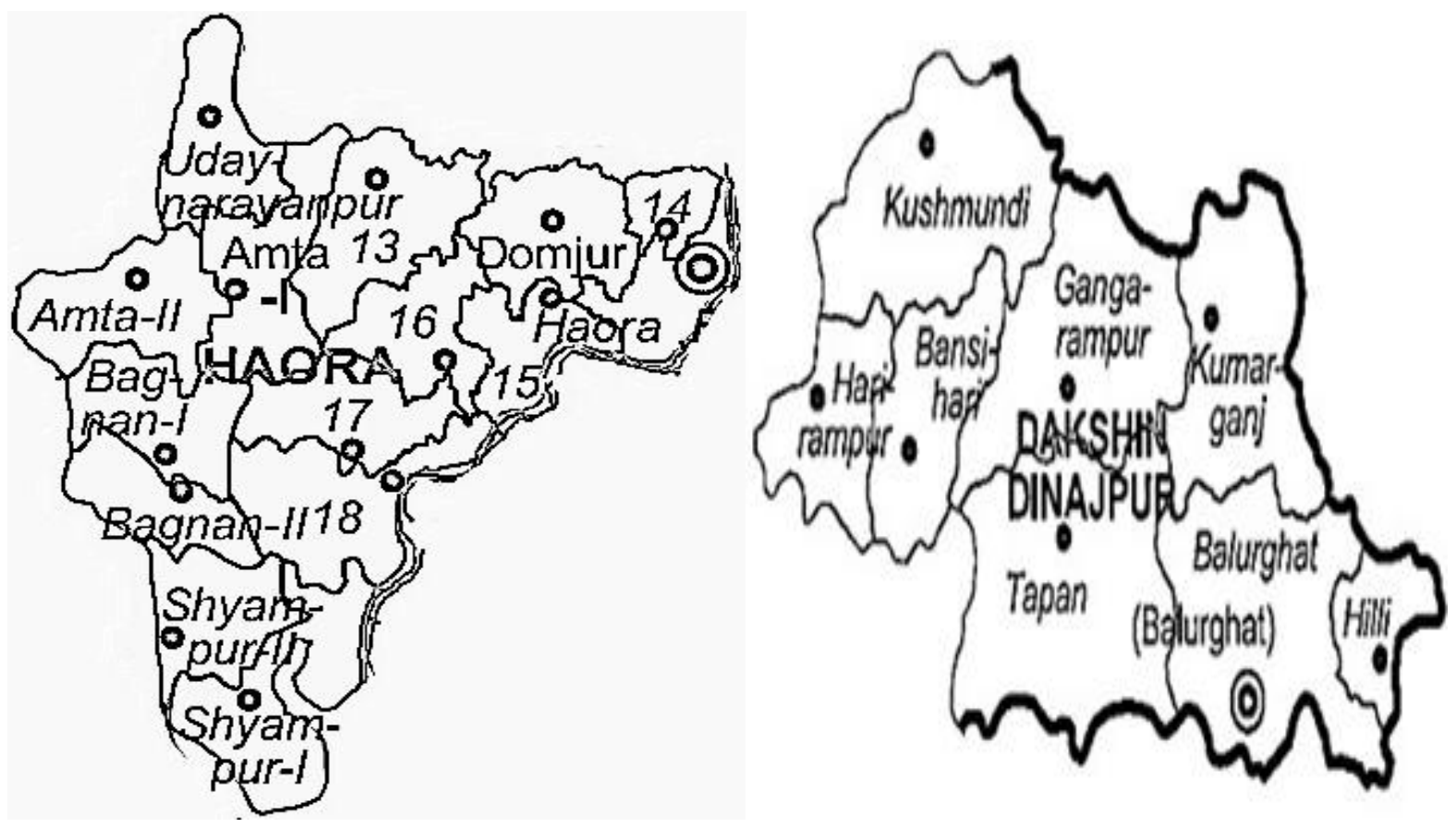
Fig.3 Graphical representation of the deficient, low, medium and high content of available S (mg $\mathrm{kg}^{-1}$ ) in soil samples of Howrah and South Dinajpur district
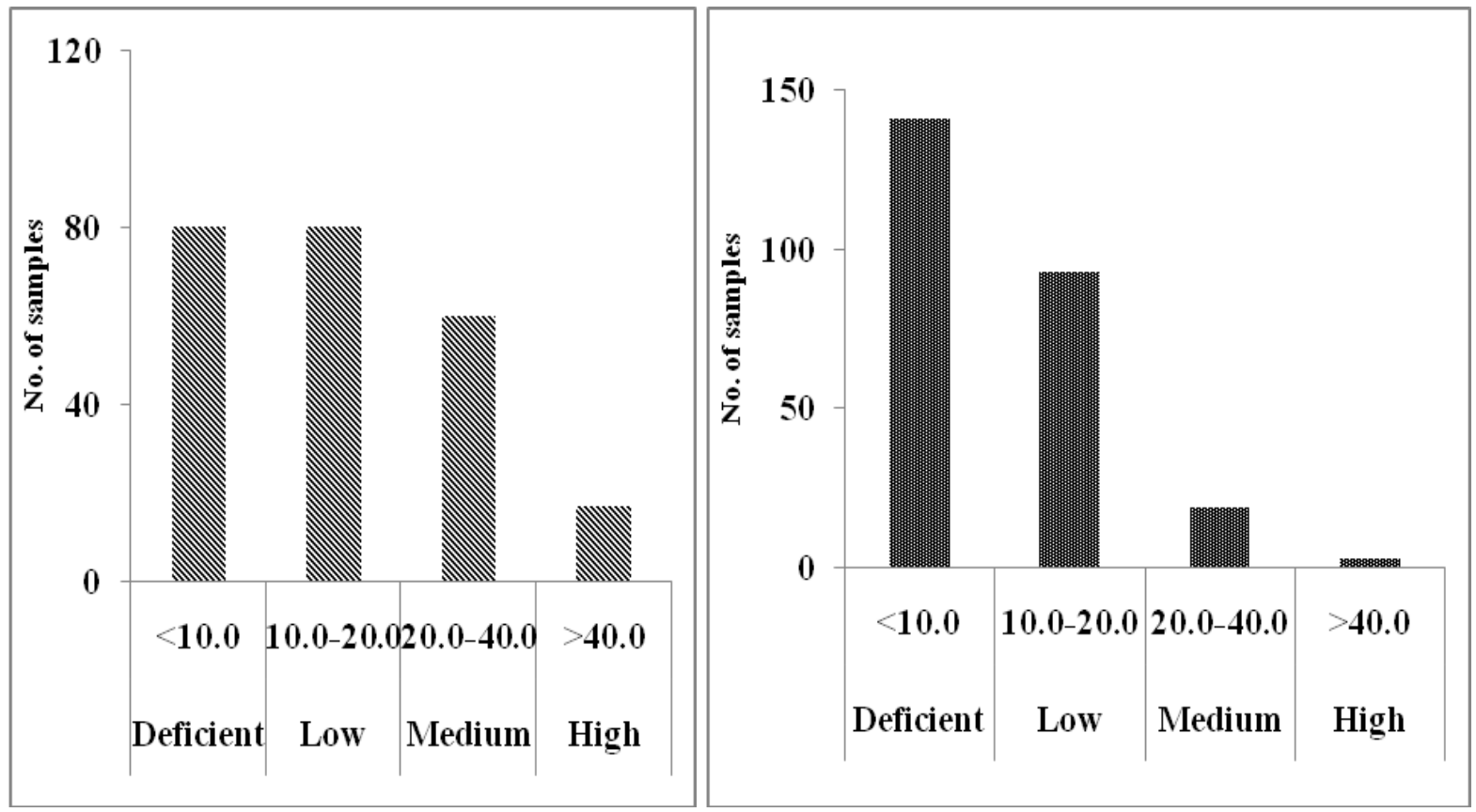

Fig.4 GPS-GIS based S delineation map of the Howrah and South Dinajpur district
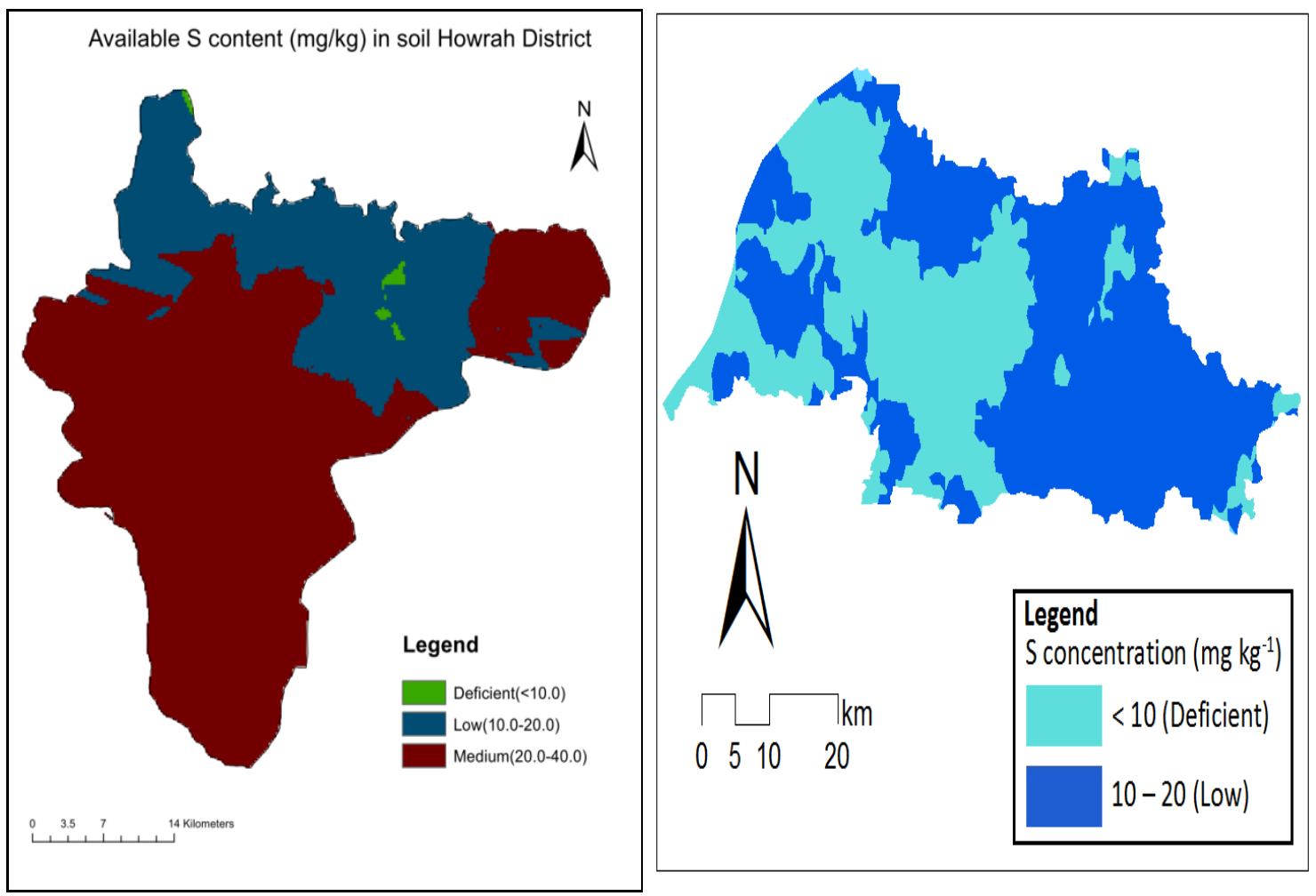
Results of available $S$ content in soils of South Dinajpur district showed that it ranged from 2.03 to $43.39 \mathrm{mg} \mathrm{kg}^{-1}$ with a mean value of $10.52 \mathrm{mg} \mathrm{kg}^{-1}$ (Table 4). Here also results showed that most of the soil samples are in deficient $(55.08 \%)$, low $(36.3 \%)$ category and medium (7.4\%) and only a very few samples $(1.1 \%)$ are high in S. NIV calculation (NIV $=1.10$ ) also revealed that available $S$ status of South Dinajpur district was in low category (Table 4 and Fig. 3).

\section{Soil fertility status}

GPS-GIS based $S$ delineation map of the Howrah and South Dinajpur district has been drawn that showed the soil of Howarh district was medium in Sulphur (Fig. 4) and deficient to low in South dinajpur district (Fig. 4).

\section{References}

Arunageetha, S., 2001. Evaluation of sulphur material on the yield and quality of soyabean and black gram. Ph.D. thesis, Tamil Nadu Agricultural University, Coimbatore.

Basak, R.K., D. Ghosh, G. Sen and Bhattacharya S. 2002. Soil pH status of Amdanga block in West Bengal soils. Environment and Ecology 23(spl-3): 640-641.

Dolui, A.K. and Pramanik, T.K. 2001. Vertical distribution of sulphur in some alfisols of West Bengal. Indian Agriculturist, 45(1-2): 33-41.

Jena, D., R. Sahoo, D.R. Sarangi and Singh, M.V. 2006. Effect of different sources and levels of sulphur on yield and nutrient uptake by groundnut- rice cropping sequence in an Inceptisol of Orissa. Journal of Indian Society of Soil Science, 54(1): 126-129.

Mandal, S. and Gupta, S.P. 1979. pH of West Bengal soils. Journal of Indian Society of Soil Science, 44: 340-343.
Maragatham, S., 2001. Evaluation of Cochin refinery material on yield and quality of sunflower and sesame. Ph.D. thesis, Tamil Nadu Agricultural University, Coimbatore.

Motsara, M.R., 2002. Available nitrogen, phosphorus and potassium status of Indian soils as depicted by soil fertilizer maps. Fertilizer News, 47(8): 15-21.

Mukhopadhyay, P. and Mukhopadhyay, A.K. 1980. Status and distribution of different forms of sulphur in some typical soil profiles of West Bengal. Journal of Indian Society of Soil Science, 28: 454-459.

Narendranath, V., 2005. Studies on sulphur nutrition of finger millet under varying soil fertility levels. M.Sc. Thesis, Tamil Nadu Agricultural University, Coimbatore.

Ramamoorthy, B. and Bajaj, J.C. 1969. Available N, P and K status of Indian soils. Fertilizer News, 14(8):24-26.

Renukadevi, A., G. Radhakrishnan, P.V. Jagadeeswari and Lakkawar, V.W. 2002. Sulphur in soil - An overview. In: National seminar on recent trends in sulphur and silicon nutrition of crops held at Madurai on June 12-13.

Sahrawat K.L., S.P. Wani, T.J. Rego, G. Pardhasarthi and Murthy, K.V.S. 2007. Widespread deficiencies of sulphur, boron and zinc in dryland soils of the Indian semi-arid tropics. Current Science, 93(10): 1428-1432.

Sankaran, K., 1989. Investigation in sulphur status of Tamil Nadu soils. Ph.D. thesis, Tamil Nadu Agricultural University, Coimbatore.

Sarkar, M., 1996. Studied of distribution of different forms of sulphur in some soils of West Bengal, M.Sc. (Ag). Thesis in Bidhan Chandra Krishi Viswavidyalaya, Nadia, West Bengal.

Singh, M.V. 2009. Micronutrient nutritional 
problems in soils of India and improvement for human and animal health. Indian Journal of Fertilizer, 5(4): 11-16, 19-26 and 56.

Singh, U.K. and Sanyal, S.K. 2001. Potassium and Aluminium dynamics in acid soils under different rates of lime application. Journal of Indian Society of Soil Science, 49: 64-70.

Singh, R.P. and Mishra, S.K. 2012. Available macro nutrients $(\mathrm{N}, \mathrm{P}, \mathrm{K}$ and $\mathrm{S})$ in the soils of chiraigaon block of district Varanasi (U.P.) in relation to soil characteristics. Indian Journal of Scientific Research, 3(1): 97-100.

Williams, C.H. and Steinbergs, A. 1959. Soil sulphur fractions as chemical indices of available sulphur in some Australian soils. Australian Journal of Agricultural Research 10: 340-352.

\section{How to cite this article:}

Rahul Kumar, Gora Chand Hazra, Ruma Das, Shyam Prasad Majumder and Amal Chandra Das. 2019. Nutrient Index of Available S in Soils of Howrah and South Dinajpur Districts of West Bengal, India. Int.J.Curr.Microbiol.App.Sci. 8(04): 1024-1032.

doi: https://doi.org/10.20546/ijcmas.2019.804.119 